\section{The effects of accounting knowledge, entrepreneurial traits, and subjective norms on the use of accounting information in investment decision making (case study on MSME actors in Gunungkidul Regency)}

\author{
Firdha Rahmiyanti, ${ }^{1}$ Reza Adellya Pratiwi, ${ }^{2}$ \\ Heny Yuningrum, ${ }^{3}$ Muyassarah ${ }^{4}$
}

1,2,3,4Universitas Islam Negeri Walisongo Semarang, Indonesia email: reza.adellya@gmail.com

\begin{abstract}
Purpose - The purpose of this study is to determine the effects of accounting knowledge, entrepreneurial traits, and subjective norms on the use of accounting information on making investment decisions of MSME actors in Gunungkidul Regency.
\end{abstract}

Method - This study uses quantitative research methodology by purposive sampling. The gathered data in this study were processed using the SPSS program. This study was carried out on 20 February to 20 March 2020. The population in this study was businessmen of MSMEs in Gunungkidul Regency who had used accounting documentation. The research took 60 respondents as a sample of the study.

Result-This study resulted that the variables of accounting knowledge and entrepreneurial traits have a positive and significant effect on the use of accounting information in making investment decisions of MSME actors in Gunungkidul Regency; While the subjective norms variable does not have a positive and significant effect on the use of accounting information in making investment decisions of MSME actors in the Gunungkidul Regency.

Implication - Future research can expand the object of research in several other regencies and can add other research variables.

Originality - The researchers added an independent variable that is subjective norms and entrepreneurial traits, whereas the previous researchers only used accounting knowledge as the independent variable.

Keywords: accountingknowledge; entrepreneurial traits; subjective norms; accounting information

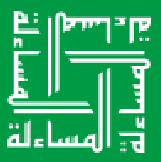

Journal of Islamic Accounting and Finance Research 
Firdha Rahmiyanti, Reza Adellya Pratiwi, Heny Yuningrum, Muyassarah

\section{Introduction}

The development of globalization today is affecting economic growth in Indonesia to be more rapid. The increasing needs and high cost of living JIAFR | 296 requires someone to think even harder in spending their money. Many people invest to get their welfare where investment is one of the solutions in obtaining additional income to meet their daily needs. Investment is also touted as the first step towards production activities and is one of the factors in increasing community economic growth (Sari, 2017). An investment is not only limited to investment in shares, sukuk, or bonds but also can be done through entrepreneurship. Micro, Small, and Medium Enterprises (MSMEs) are forms of a business unit that is managed by individuals and groups in the community where MSMEs can move to various types of businesses.

Sari \& Dwirandra (2015) state that making an investment decision can be done by utilizing accounting information. Accounting information is all information or data that can be accounted for originality related to the financial statements of a company or business that is run which contains records of various transactions that occur during the business running, and from that information, we can find out the profit/loss of business that we get. Accounting information is useful for providing information and considerations in allocating available resources for investment decision making. The obligation to conduct good accounting records aimed at MSME actors has also been regulated in Law No. 9 of 1995 concerning Small Businesses and taxation Law No. 2 of 2007 concerning the Development of Small and Medium Businesses and Cooperatives.

The behavior of entrepreneurs in using accounting information in making investment decisions can be explained through the Theory of Planned Behavior (TPB) which consists of perceived behavioral control which is understood as accounting knowledge and attitudes towards behavior which is understood as an entrepreneurial trait. Through this theory, we can see the extent to which MSME entrepreneurs' perceptions of accounting knowledge 
The effect of accounting knowledge, entrepreneurial traits, and subjective norms on ...

and entrepreneurial trait can influence the consideration of investment decision making (Juniariani \& Wirakusuma, 2016).

Latief (2018) stated that there are still many MSMEs in Indonesia who do not understand accounting in spite of the fact that accounting knowledge has a large role in the continuity of the business that we run. Accounting JIAFR | 297 knowledge can help us in tracking financial information to find out whether the business is running well or not and whether our business can last for a long time or not.

Deane (2019) said, based on data from the Small Business Association (SBA), more than half of new businesses experienced failures during the first year. There were $66 \%$ during the first ten-year opening, 50\% during the first five-year opening, and 30\% during the first two-year opening from new businesses that failed. In addition, there are 2 out of 3 MSMEs that failed because they used a bad capital structure, overpay when starting a business, lack of cash reserves, and poor accounting controls.

Nowadays more and more MSMEs do business investment by opening branches of their businesses in other regions, but not a few of them are forced to close their businesses. This is due to the low entrepreneurial traits possessed by MSMEs and the lack of utilization of accounting information. A research conducted by Kristanti (2012) found that someone who has high entrepreneurial traits can influence the use of accounting information in investment decision making related to his business. He will use the accounting information to see the development of his business so that the information is used as a basis for investment decision making.

In line with Kristianti, research conducted by Juniariani and Wirakusuma (2016) found that entrepreneurs who have high entrepreneurial traits tend to do anything to develop their business, including by using accounting information in making investment decisions. The higher one's entrepreneurial traits, the higher the curiosity associated with accounting information. In contrast, different results are shown by Putra and Arizona's (2016) research which states that the use of accounting information in 
investment decision making is not influenced by the entrepreneurial traits possessed by business actors.

Based on previous studies, it was found that there were inconsistencies in the results of previous researchers which then motivated the researchers to conduct this research using the same variables to prove whether the use of accounting information in investment decision making is influenced by the entrepreneurial traits of the business actor. Subjective norms variable as the independent variable is also added in this study because it did not only aim to examine the internal factors (accounting knowledge and entrepreneurial traits) but also to find out whether external factors can influence the use of accounting information as a basis for making an investment decision by MSMEs.

Subjective norms are perceptions or input given by others that are used as a benchmark for an individual for all activities to be carried out. In the investment context, subjective norms are interpreted as one's view of social pressures that influence one's judgment in carrying out investment activities.

\section{Literature Review}

Accounting knowledge is financial information that is used as the basis for making a decision through a series of processes of recording, grouping, and summarizing related to economic events in an orderly and logical manner (Sianturi \& Fathiyah, 2016). Accounting knowledge is also said to be both truth and a clear understanding of what is seen as a fact (Sianturi \& Fathiyah, 2016). Accounting knowledge is a real perception of the facts or information about recording, classification, summarizing, and reporting on economic events and transactions that occur in a company and produce output in the form of financial information that is used as a basis for making corporate decisions.

In addition to accounting knowledge, entrepreneurial traits are also important in business. The entrepreneurial trait is a business or action owned by someone which is shown through creative and innovative behavior in handling business activities that are carried out, to obtain large profits, by 
The effect of accounting knowledge, entrepreneurial traits, and subjective norms on ...

always trying to serve customers better and create and provide products that are more useful and creating efficient ways of working (Istiariani, 2020).

Another important factor is subjective norms. Kapantouw and Mandey (2015) mention subjective norms as an impulse of one's interest to do or not do a certain behavior that is influenced by the person's perception or view of JIAFR | 299 the beliefs of others.

The role of accounting in MSMEs is to provide financial information that is important for MSME entrepreneurs in conducting their business. Kuncoro (2017) mentioned the information including: 1) Company performance information, serves to determine the amount of profit/loss through the company's income statement, where the information is used as a tool to evaluate company performance. 2) Tax calculation information, serves to find out the nominal amount of tax that must be paid by the company in a certain period, which can be seen through the tax report that has been made. 3) Information on the position of company funds, accounting records function to provide information about the position of the company's funds which can be seen through the balance sheet where the balance sheet can provide information about the use of assets and the total acquisition of business funds dominated by debt or equity. 4) Information on changes in the owner's capital, accounting records function to provide information about the source of funding obtained and changes in the capital that occur in a business. 5) Cash income and expenditure information, the information needed is related to the acquisition and use of the main assets in the form of cash can be seen from the cash flow statement that has been made. 6) Activity planning information, information related to the description of planning a business in the future can be seen through the budget report that has been made. 7) Cost information, accounting records aim to measure the costs incurred in the business.

Financial statements as accounting information are made to provide information about the financial position, company performance, and changes in the financial position of a company that is useful in making economic 
Firdha Rahmiyanti, Reza Adellya Pratiwi, Heny Yuningrum, Muyassarah

decisions. One example of economic decision making for a company or entrepreneur is an investment decision.

Prananda and Datu (2016) define decision making as the process of selecting an action that is used as a step in solving problems where the decision is taken deliberately, not by accident, and should not be arbitrary. Decision making is used to solve a problem with certain techniques that have been approved and can be accepted by all parties. Before making a decision, the problem is formulated first, then the solution is based on the selection of the best alternative available.

\section{Hypothesis Development}

Based on the theories which are strengthened by the explanation and results of previous studies, the research hypothesis can be formulated as follows:

$\mathrm{HO}_{1}$ : Accounting knowledge does not positively influence the use of accounting information in investment decision making

$H_{1}$ : Accounting knowledge positively influences the use of accounting information in investment decision making

$\mathrm{HO}_{2}$ : Entrepreneurial traits do not positively influence the use of accounting information in investment decision making

$\mathrm{H}_{2}$ : Entrepreneurial traits have a positive influence the use of accounting information in investment decision making

$\mathrm{HO}_{3}$ : Subjective norms do not positively influence the use of accounting information in investment decision making

$\mathrm{H}_{3}$ : Subjective norms have a positive influence the use of accounting information in investment decision making

\section{Research Methods}

This research uses quantitative method where the data were taken in the form of numerical data or numbers that can be measured with certainty. Then the results of these measurements were analyzed. The variables in this 
The effect of accounting knowledge, entrepreneurial traits, and subjective norms on ...

study consisted of independent variables, namely accounting knowledge, entrepreneurial traits, and subjective norms, and one dependent variable, namely accounting information in investment decision making.

The data used in this study are primary data types. Primary data is data taken directly by researchers from the object of research conducted. The main data in this study were obtained directly from data sources, namely the owners or managers of the small and medium businesses (MSMEs) of Gunungkidul Regency.

This study uses data analysis method that is by testing the validity and testing the reliability of the questions posed by researchers to respondents in the questionnaire. Siregar (2013) states that a question is called reliable if it shows the same results after several measurements using the same tool for the same symptoms. In addition, Ghozali (2005) says that an instrument is considered valid if the questions given can reveal something that is measured by the questionnaire to be studied.

Table 1. Research Instruments

\begin{tabular}{|c|c|c|c|}
\hline Variable & $\begin{array}{c}\text { Definition of } \\
\text { Operational } \\
\text { Variables }\end{array}$ & Indicator & Measurement Scale \\
\hline $\begin{array}{l}\text { Accounting } \\
\text { knowledge } \\
\text { (X1) }\end{array}$ & $\begin{array}{l}\text { Accounting } \\
\text { knowledge is the } \\
\text { ability of MSME } \\
\text { business actors in } \\
\text { terms of knowing } \\
\text { or understanding } \\
\text { the aims and } \\
\text { objectives related } \\
\text { to various things } \\
\text { contained in } \\
\text { accounting } \\
\text { information. }\end{array}$ & $\begin{array}{l}1 \text { Knowledge of } \\
\text { financial } \\
\text { statements. } \\
2 \text { Knowledge of } \\
\text { financial ratios. } \\
3 \text { Knowledge of } \\
\text { cost accounting. }\end{array}$ & $\begin{array}{l}\text { Measured using the } \\
\text { instruments used by } \\
\text { Bonner and Walker. } \\
\text { Where the answer to this } \\
\text { question can only be } \\
\text { chosen with one correct } \\
\text { answer (a, b, c, d, e). }\end{array}$ \\
\hline $\begin{array}{l}\text { Entreprene } \\
\text { urial Traits } \\
\text { (X2) }\end{array}$ & $\begin{array}{l}\text { An entrepreneurial } \\
\text { trait is a business or } \\
\text { action that is } \\
\text { owned by an }\end{array}$ & $\begin{array}{l}1 \text { Courage to take } \\
\text { risks. } \\
2 \text { Innovation. }\end{array}$ & $\begin{array}{l}\text { Measured by a } \\
\text { questionnaire scale and } \\
\text { using a Likert scale. }\end{array}$ \\
\hline
\end{tabular}


Firdha Rahmiyanti, Reza Adellya Pratiwi, Heny Yuningrum, Muyassarah

\begin{tabular}{|c|c|c|c|c|}
\hline & $\begin{array}{l}\text { MSME business } \\
\text { actor that is shown } \\
\text { through creative } \\
\text { and innovative } \\
\text { behavior in } \\
\text { handling business } \\
\text { activities that are } \\
\text { carried out. }\end{array}$ & $\begin{array}{l}3 \\
4 \\
5 \\
6\end{array}$ & $\begin{array}{l}\text { Confident. } \\
\text { Result oriented. } \\
\text { Future-oriented. } \\
\text { Have an opinion } \\
\text { in interpreting } \\
\text { tenacity and } \\
\text { responsibility. }\end{array}$ & \\
\hline $\begin{array}{l}\text { Subjective } \\
\text { norms (X3) }\end{array}$ & $\begin{array}{l}\text { Subjective norms } \\
\text { are the beliefs of } \\
\text { MSME business } \\
\text { actors in following } \\
\text { suggestions and } \\
\text { opinions from the } \\
\text { surrounding } \\
\text { environment to } \\
\text { carry out an } \\
\text { investment activity } \\
\text { in their business } \\
\text { which is measured } \\
\text { based on normative } \\
\text { beliefs. }\end{array}$ & 1 & $\begin{array}{l}\text { Confidence in } \\
\text { the role of } \\
\text { support from } \\
\text { family and } \\
\text { friends. } \\
\text { Confidence in } \\
\text { following the } \\
\text { suggestions and } \\
\text { opinions of } \\
\text { family and } \\
\text { friends. } \\
\text { Tendency to } \\
\text { follow other } \\
\text { people's } \\
\text { behavior. }\end{array}$ & $\begin{array}{l}\text { Measured by a } \\
\text { questionnaire scale and } \\
\text { using a Likert scale. }\end{array}$ \\
\hline $\begin{array}{l}\text { Accounting } \\
\text { information } \\
\text { in making } \\
\text { investment } \\
\text { decisions }(\mathrm{Y})\end{array}$ & $\begin{array}{l}\text { Accounting } \\
\text { information in } \\
\text { making investment } \\
\text { decisions is a } \\
\text { financial report } \\
\text { prepared by MSME } \\
\text { business actors } \\
\text { which are used as } \\
\text { the basis for making } \\
\text { investment } \\
\text { decisions in their } \\
\text { business. }\end{array}$ & 1 & $\begin{array}{l}\text { The amount of } \\
\text { accounting } \\
\text { information is } \\
\text { used for making } \\
\text { accounting } \\
\text { decisions. } \\
\text { This accounting } \\
\text { information } \\
\text { includes balance } \\
\text { sheets, L/ R } \\
\text { reports, changes } \\
\text { in capital, cash } \\
\text { flows, } \\
\text { production costs, } \\
\text { and financial } \\
\text { ratios. }\end{array}$ & $\begin{array}{l}\text { Measured by a } \\
\text { questionnaire scale and } \\
\text { using a Likert scale. }\end{array}$ \\
\hline
\end{tabular}


The effect of accounting knowledge, entrepreneurial traits, and subjective norms on ...

\section{Results and Discussion}

\section{Multiple Regression Analysis}

The results of the multiple linear regression analysis are presented in table 2. Based on the multiple linear regression analysis test in table 2 , it can be concluded that:

\section{Constant Value}

It is found that the constant value is 6.930. This figure means that if accounting knowledge (X1), entrepreneurial traits (X2), and subjective norm (X3) are 0 , then the use of accounting information in investment decision making $(\mathrm{Y})$ is 6.930 .

\section{Regression coefficient X1}

It is found that the regression coefficient X1 value is 0.324 . This means that if the accounting knowledge of Gunungkidul MSME actors increased, in this case, namely the use of accounting information used in investment decision making. The desire of MSME actors for investment decision making increased by $32.4 \%$ assuming that the other independent variable is ceteris paribus.

\section{Table 2. Regression Analysis}

\section{Coefficients $^{\mathrm{a}}$}

\begin{tabular}{|c|c|c|c|c|c|c|c|c|}
\hline & & \multicolumn{2}{|c|}{$\begin{array}{l}\text { Unstandardized } \\
\text { Coefficients }\end{array}$} & \multirow{2}{*}{$\begin{array}{c}\text { Standardized } \\
\text { Coefficients } \\
\text { Beta } \\
\end{array}$} & \multirow[b]{2}{*}{$\mathrm{T}$} & \multirow[b]{2}{*}{ Sig. } & \multicolumn{2}{|c|}{ Collinearity Statistics } \\
\hline \multicolumn{2}{|c|}{ Model } & $\mathrm{B}$ & Std. Error & & & & Tolerance & VIF \\
\hline \multirow[t]{4}{*}{1} & (Constant) & 6,930 & 3,369 & & 2,057 & 045 & & \\
\hline & $\mathrm{x} 1$ & ,324 & 139 & ,441 & 2,326 & ,024 & ,232 & 4,307 \\
\hline & $x 2$ & 311 & 154 & 347 & 2,018 & ,049 & 281 & 3,556 \\
\hline & $x 3$ & ,040 & 263 & ,023 & 153 & 879 & 381 & 2,626 \\
\hline
\end{tabular}

a. Dependent Variable: $y$ 


\section{Regression coefficient X2}

It is found that the regression coefficient of $\mathrm{X} 2$ is 0.311 . This means that if the entrepreneurial traits of Gunungkidul Regency MSMEs increased, in this JIAFR | 304 case, namely the use of accounting information used in investment decision making. The desire of MSMEs for investment decision making increased by $31.1 \%$ assuming that the other independent variable is ceteris paribus.

\section{Regression coefficient X3}

It is found that the regression coefficient $\mathrm{X} 3$ value is 0.04 . This means that if the subjective norms of the Gunungkidul Regency MSMEs increased, in this case, namely the use of accounting information used in investment decision making. The desire of MSMEs on investment decision making increased by $4 \%$ assuming that the other independent variable is ceteris paribus. But the subjective norm variable does not give any effect.

\section{Coefficient of Determination $\left(R^{2}\right)$}

This research was conducted to find out the percentage of the contribution of the independent variable to the dependent variable. Table 3 shows the results of the coefficient of determination test conducted by researchers.

Based on table 3, it can be seen that the magnitude of the coefficient of determination of research is 0,600 or $60 \%$. This means that $60 \%$ of the use of accounting information in making investment decisions on MSMEs of Gunungkidul Regency is influenced by accounting knowledge, entrepreneurial traits, and subjective norms.

Table 3. Coefficient of Determination $\left(\mathbf{R}^{2}\right)$

Model Summaryb

\begin{tabular}{ccccc}
\hline Model & $\mathrm{R}$ & $\mathrm{R}$ Square & Adjusted R Square & Std. Error of the Estimate \\
\hline 1 &, $775^{\mathrm{a}}$ &, 600 &, 575 & 3,846 \\
\hline
\end{tabular}

a. Predictors: (Constant), x3, x2, x1

b. Dependent Variable: $y$ 
The effect of accounting knowledge, entrepreneurial traits, and subjective norms on ...

\section{Partial Test (T)}

This test is carried out to find out how far the influence of independent variables on the dependent variable using statistical tests (t-test) is. The research hypothesis criteria can be accepted if the value of $t$ count $>$ value of $t$ table. Likewise, the research hypothesis is rejected if the calculated $t$ value $<t$ table value. The value of $t$ table is $\{(0.05: 2,52-3-1)=0.025,48\}=0.67964\}$. The results of testing the hypothesis of the t-test conducted by researchers are shown in table 4.

Based on table 4 it can be seen that: 1) Accounting knowledge, it is obtained that the $t$ value is 2.326 and the significance level is 0.024 . So it can be concluded that the accounting knowledge variable significantly influences the use of accounting information in investment decision making for Gunungkidul SMEs. This is because the calculated $t$ value is greater than the $t$ table value and the significance level is below 0.05 . Therefore $\mathrm{H} 1$ is accepted and $\mathrm{HO}$ is rejected. 2) Entrepreneurial traits, it is obtained that the t value is 2.018 and the significance level is 0.049 . So it can be concluded that the entrepreneurial traits variable significantly influences the use of accounting information in making investment decisions on the MSMEs of Gunungkidul Regency. This is because the calculated $t$ value is greater than the $t$ table value and the significance level is below 0.05 . Therefore $\mathrm{H} 2$ is accepted and $\mathrm{HO}$ is rejected.

Table 4. Partial Test (T) Result

\begin{tabular}{|c|c|c|c|c|c|c|c|c|}
\hline \multicolumn{9}{|c|}{ Coefficients $^{a}$} \\
\hline & & \multicolumn{2}{|c|}{$\begin{array}{l}\text { Unstandardized } \\
\text { Coefficients }\end{array}$} & \multirow{2}{*}{$\begin{array}{c}\text { Standardized } \\
\text { Coefficients } \\
\text { Beta } \\
\end{array}$} & \multirow[b]{2}{*}{$\mathrm{T}$} & \multirow[b]{2}{*}{ Sig. } & \multicolumn{2}{|c|}{$\begin{array}{l}\text { Collinearity } \\
\text { Statistics }\end{array}$} \\
\hline \multicolumn{2}{|c|}{ Model } & B & Std. Error & & & & Tolerance & VIF \\
\hline \multirow[t]{4}{*}{1} & (Constant) & 6,930 & 3,369 & & 2,057 & ,045 & & \\
\hline & $\mathrm{x} 1$ & 324 & 139 & ,441 & 2,326 & ,024 & 232 & 4,307 \\
\hline & $x 2$ & 311 & 154 & 347 & 2,018 & ,049 & 281 & 3,556 \\
\hline & $x 3$ & , 040 & ,263 & ,023 & ,153 & ,879 & ,381 & 2,626 \\
\hline
\end{tabular}

a. Dependent Variable: $y$ 
3) T-test subjective norm variables, it is obtained that the t value is 0.153 and the significance level is 0.879 . So it can be concluded that the subjective norm variable does not significantly influence the use of accounting information in investment decision making for Gunungkidul MSMEs. This is because the calculated $t$ value is smaller than the $t$ table value and the significance level is above 0.05 . Therefore $\mathrm{HO}_{3}$ is accepted and $\mathrm{H} 3$ is rejected.

\section{Discussion of Research Data Analysis Results}

This research was conducted on the MSMEs of Gunungkidul Regency regarding the effect of independent variables (accounting knowledge, entrepreneurial traits, and subjective norms) on the dependent variable (use of accounting information in investment decision making). The results of the data analysis can be explained as follows:

The magnitude of the coefficient of determination on the contribution of the independent variable (accounting knowledge, entrepreneurial traits, and subjective norms) to the dependent variable (the use of accounting information in making investment decisions) is 0.60 or $60 \%$. This shows the ability of the independent variable in explaining the dependent variable is $60 \%$, where the rest is explained by other factors outside the independent variable used by the researcher.

Based on testing ( $t$-test), the results show that the calculated $t$ value on the accounting knowledge variable is 2.326 and the significance level is 0.024 . So it can be concluded that the accounting knowledge variable has a positive and significant influence on the use of accounting information in investment decision making in Gunungkidul MSMEs because the significance is below 0.05 . The accounting knowledge in this study refers to knowledge related to financial statements, cost accounting, financial ratios, and the methods used for valuing business investments, which can be obtained through formal learning both in schools and universities and through special training. This research shows that the Gunungkidul Regency MSMEs already have an understanding of accounting related to financial statements, cost accounting, financial ratios, and the methods used in investment valuation that encourage 
The effect of accounting knowledge, entrepreneurial traits, and subjective norms on ...

them to use accounting information in making investment decisions. With good accounting knowledge, business actors can record financial statements appropriately and can separate business capital from personal money, and can understand the contents of the accounting information. The output from recording financial statements is then used as a basis for assessing and JIAFR | 307 considering investment decisions that will be made. The researchers consider that it is necessary for MSMEs Gunungkidul Regency to further enhance understanding related to financial ratios and investment valuation methods. This is because financial ratios can be used as information related to business performance and financial capabilities of the business, and investment valuation methods can be used as a basis for knowing the amount of profit to be invested and whether the amount is feasible to be invested to obtain the maximum return. The results of this study are consistent with research conducted Putra et al. (2016) which states that accounting knowledge has a positive and significant effect on the use of accounting information in making investment decisions.

Based on testing (t-test), the results show that the calculated $t$ value on the variable entrepreneurial traits is 2.018 and the significance level is 0.049 . So it can be concluded that the variable of entrepreneurial traits has a positive and significant influence on the use of accounting information in investment decision making in Gunungkidul MSMEs because the significance is below 0.05 . The entrepreneurial traits in this study refer to the courage of business actors in taking risks, innovating, confident in their business, results-oriented, and future, as well as being responsible for the business being managed. The research shows that the Gunungkidul MSMEs have entrepreneurial traits associated with courage in taking risks, innovating, confident in their business, results-oriented, and future, as well as being responsible for the business being managed to encourage them to use accounting information in decision-making investment. The results of this study prove that the high level of one's entrepreneurial traits influences the high use of accounting information in making accounting decisions. This is because if businesses have high entrepreneurial traits, they tend to have the desire to enlarge their 
business scale, which in turn can trigger business actors to use accounting information that is used as a basis for investment decision making. Accounting information is used here by business actors as a tool to see the financial condition of the business and the amount of profit obtained during the business carried out. The researchers consider that MSMEs of Gunungkidul Regency must increase their entrepreneurial traits related to courage in taking risks and innovating in business. Therefore, MSMEs can increase competitiveness in business competition and increase business productivity, while MSMEs can provide something interesting and different from other businesses so that it can attract buyers and increase the amount of marketing. The results of this study are consistent with research conducted by Juniariani et al. (2016) which states that entrepreneurial traits have a positive and significant effect on the use of accounting information in investment decisions to be made. However, the results of this study are not consistent with research conducted by Putra et al. (2016) which states that entrepreneurial traits do not have a positive and significant effect on the use of accounting information in investment decision making.

Based on testing (t-test), the results shows that the calculated $t$ value on the subjective norm variable is 0.153 and the significance level is 0.879 . So it can be concluded that the subjective norm variable does not have a positive and significant effect on the use of accounting information in investment decision making in Gunungkidul MSMEs because the significance is above 0.05 . Subjective norms in this study refer to the support and advice given by family and friends of MSME actors for the use of accounting information in making investment decisions. The effect of the variable subjective norm does not affect the use of accounting information in making investment decisions on Gunungkidul MSMEs because accounting information that has been made by MSME actors can be seen by managers and business owners only. So that investment decision making can only be done based on considerations and agreements between managers and business actors without considering suggestions or opinions from other parties. 
The effect of accounting knowledge, entrepreneurial traits, and subjective norms on ...

\section{Conclusion}

By considering the data obtained, the tests conducted, as well as the analysis results, it can be concluded that accounting knowledge has a positive influence on the use of accounting information on investment decision making. The results of this study prove that the ability in accounting is very JIAFR | 309 much needed by MSME actors. Accounting knowledge is used to understand accounting information in investment decision making. The higher the accounting knowledge MSME actors, the higher the utilization of accounting information in order to make investment decisions.

The entrepreneurial traits have a positive effect on use of accounting information in manufacturing investment decision. The higher the person's entrepreneurial traits, the higher curiosity about accounting information and the use of accounting information in making business investment decisions. Entrepreneurs who have high entrepreneurial traits tend to do anything for the sake of the development of the company as well as use accounting information in making each decision relating to his company.

Subjective norm variables do not have a positive and significant effect on the use of accounting information in making investment decisions for MSME actors because the accounting formations that have been made by MSMEs can only be seen by managers and business owners. So that investment decision making can only be made based on considerations and agreements between managers and business actors without considering suggestions or opinions from other parties.

\section{References}

Investopedia. (2019, Juni 25). Top 6 Reasons New Businesses Fail. Dipetik Desember 25, 2019, dari www.investopedia.com/financialedge/1010/top-6-reasons-new-businesses-fail.aspx.

Istiariani, I. (2020). Ethic and the affecting factors: Insights from sharia accounting students. Journal of Islamic Accounting and Finance Research, 2(1), 1-26. 
Juniariani, N. M., \& Wirakusuma, M. G. (2016). Pengaruh Pengetahuan Akuntansi Dan Jiwa Kewirausahaan Pada Penggunaan Informasi Akuntansi Dalam Pembuatan Keputusan Investasi.

JIAFR | 310

Kapantouw, C., \& Mandey, S. L. (2015). Pengaruh Sikap, Norma Subyektif, Dan Gaya Hidup Terhadap Keputusan Pembelian Handphone Asus Di Gamezone Computer Mega Mall Manado.

Kompas.com. (2018, Agustus 30). Masih Banyak Pelaku MSME "Buta" Akuntansi. Dipetik Desember 20, 2019, dari www.google.com/amp/s/amp.kompas.com/ekonomi/read/2018/08 /30/144531526/masih-banyak-pelaku-MSME-butaakuntansi?espv=1.

Kristanti, N. P. (2012). Pengaruh Pengetahuan Akuntansi dan Jiwa Kewirausahaan terhadap Penggunaan Informasi Akuntansi dalam Pembuatan Keputusan Investasi.

Putra, I. P., \& Arizona, I. P. (2016). Pengaruh Pengetahuan Akuntansi dan Jiwa Kewirausahaan terhadap Penggunaan Sistem Informasi Akuntansi dalam Pengambilan Keputusan Investasi.

Perkembangan Data Usaha Mikro, Kecil, Menengah (MSME) Dan Usaha Besar (UB) Tahun 2010-2015 dan 2016-2017. Dipetik Desember 2019, 2019, dari www.depkop.go.id/data-MSME.

Sari, D. R. (2017). Pengaruh Literasi Keuangan, Pendapatan, dan Pendidikan Terhadap Keputusan Investasi. STIE Perbanas Surabaya.

Sari, N. M., \& Dwirandra, A. A. (2015). Pengaruh Kepribadian Wirausaha dan Pengetahuan Akuntansi pada Penggunaan Informasi Akuntansi dalam Pembuatan Keputusan Investasi.

Sianturi, H., \& Fathiyah, N. (2016). Pengaruh Persepsi Pemilik dan Pengetahuan Akuntansi Pelaku Usaha Kecil dan Menengah terhadap Penggunaan Informasi Akuntansi.

Suliati, R. (2012). Pengaruh Pelatihan Akuntansi dan Jiwa Kewirausahaan terhadap Penggunaan Informasi Akuntansi dalam Pembuatan Keputusan Berwirausaha.

Wirakusuma, M. G. (2019). Pengaruh Penggunaan Informasi Akuntansi pada Hubungan antara Jiwa Kewirausahaan dan Keputusan Investasi. 